Administrative Issues Journal: Connecting Education, Practice, and Research, Summer 2018, Vol. 8, No. 1: 28-47. DOI: 10.5929/2018.8.1.2

\title{
"Your fears are appreciated here": Exploring a humanistic approach to public speaking instruction
}

\author{
Justin D. Walton, Ph.D. \\ Cameron University
}

\begin{abstract}
Communication teachers have long been concerned with the development of students' oral communication competencies. Regrettably, public speaking remains one of the most feared communicative contexts. Though there has been extensive interest in cognitive/behavioral strategies for alleviating communication apprehension, there has been surprisingly little descriptive pedagogical research conducted on the subject within actual classroom settings. This qualitative case study examines the way one communication teacher dealt with issues of student reticence and fear in her introductory public speaking courses through the use of humanistic, student-centered principles. Findings reveal that her pedagogy emphasized (a) the expression of feelings and emotions, (b) prizing the whole student, and (c) intrinsic motivational learning. Implications for communication instruction and pedagogical research are considered.
\end{abstract}

Keywords: Humanistic education, public speaking pedagogy, instructional communication, classroom climate

S peech communication educators have long been interested in the development and improvement of students' oral communication competencies (Cronin \& Glenn, 1991; Morreale \& Backlund, 2002; Morreale \& Hackman, 1994; Schreiber, Paul, \& Shibley, 2012). Given that public speaking remains one of the most feared social situations reported by U.S. citizens (Dwyer \& Davidson, 2012; McCroskey, 1977a, 1977b; Richmond \& McCroskey, 1997), the communication field has historically made helping those afflicted with communication apprehension ${ }^{1}$ and its various cognates (e.g., reticence, unwilling to

${ }^{1}$ Communication apprehension (CA) is described as "an individual's level of fear or anxiety associated with either real or anticipated communication with another person or persons" (McCroskey, 1984, p. 13). It has been estimated that roughly 15-20 percent of the general U.S. population is afflicted with high levels of CA (Richmond \& McCroskey, 1998). Persons high in CA are commonly reluctant about communicating in various circumstances (e.g., interpersonal, group settings, public speaking). Research has shown that high CA is often associated with lower levels of self-esteem, lower grade point averages and lower levels of academic performance (McCroskey, Daly, \& Sorensen, 1976; Richmond \& McCroskey, 1998).

WALTON / DOI: 10.5929/2018.8.1.2 
communication, stage fright, speech anxiety) "a primary instructional mission" (Kelly \& Keaten, 2000, p. 45). Although there has been extensive interest in cognitive and behavioral approaches ${ }^{2}$ for treating communication anxiety (Allen, Hunter, \& Donohue, 1989; Ayres \& Hopf, 1987; Hopf \& Ayres, 1992; Robinson, 1997), there has been surprisingly little descriptive pedagogical research documenting the effectiveness of these and other comparable strategies within actual classroom settings.

Accordingly, this qualitative case study examines the way one communication teacher dealt with issues of student reticence and fear in her university public speaking courses through the use of humanistic, student-centered principles. This report is not presented as conclusive justification of the approach, but is offered as a catalyst for further conversation about ways communication anxiety may be addressed in communication and communication-related courses.

This qualitative report is organized as follows: First, I sketch out the philosophical and theoretical principles of humanistic education, introducing concepts and assumptions that informed the basis of the pedagogy examined in this study. Then I introduce the participant, outline the research methodology, and discuss the general context of the study. Next, I present and analyze the findings. Finally, implications for communication instruction and pedagogical research are considered.

With roots in phenomenological inquiry, contemporary versions of humanistic psychology underscore persons' capacities for self-directed (intrinsic) motivation, personal growth and development, individual freedom and agency, and posit a generally optimistic outlook toward human nature (Combs, 1981; Combs, Blume, Newman, \& Wass, 1974; DeCarvalho, 1991; Hamacheck, 1987; Morris, 1978; Rogers, 1969; Sage, Adcock, \& Dixon, 2012; Valett, 1977). Dr. Carl Rogers (1902-1987), an American psychologist, is frequently acknowledged as a leading architect of the perspective and its applications to personality studies, motivation and learning, and clinical psychology. Early in his career, Rogers pioneered a client-centered, or nondirective approach, to therapeutic counseling which differed extensively from popular clinical methods of the time. Rather than focusing exclusively on what the therapist did to the other-an approach which highlighted the authority, power, and intentions of the psychologist-Rogers (1980) argued that clients have within themselves "vast resources for self- understanding and for altering their self-concepts, basic attitudes, and self-directed behavior" presuming an environment of "facilitative psychological attitudes" can be fostered within the therapeutic relationship (p. 115). In lieu of steering clients in the direction of pre-defined or pre- selected ends, the therapist provides individuals with self-guided openings for continued personal growth and reflective expression.

With the publication of his landmark book, Freedom to Learn (1969), Rogers harnessed his experiences with psychotherapy towards the development of a learner-centered view of education. Consistent with his person-centered model of adult therapy, Rogers challenged conventional conceptions of education

\footnotetext{
2 Robinson's (1997) survey of 307 colleges and universities identified four major CA reduction techniques used in introductory communication classes: (a) skills training-focus on nonverbal and verbal delivery, speech writing; (b) cognitive modification-learning to recognize and replace self-defeating attitudes and beliefs; (c) systematic desensitization-behavioral therapy based upon gradual exposure to a feararousing stimulus; and (d) visualization-modifying one's mental imagery of self-performance.
} 
which adhered to fundamentally mechanistic and reductionistic interpretations of the teaching-learning relationship. Rogers asserted that traditional instruction put emphasis on an outdated genre of learning, or what he called the "learning of nonsense syllables" (1994, p. 35). In preference to the resourcefulness and creativity of the student, Rogers held that predominate approaches to learning drew misguided attention to the teacher's capacity to convey curriculum materials and students' aptitudes to submissively imbibe empty, decontextualized information. In view of this, he argued, "education becomes the futile attempt to learn material that has no personal meaning" (1994, p. 35). On the other hand, significant experiential learning occurs when the subject matter is found to have practicality and value for students' needs, empower self-confidence and perspective-taking, and contributes to a more open and flexible view of self and reality (Rogers, 1959, 1961). Additionally, significant learning stresses students' abilities to reflect upon and use knowledge to solve problems and to exercise autonomy in the formulation of their intentions. And, since each individual's history and circumstance is distinctive (e.g., varying purposes, beliefs, worldviews and experiences), it is apparent that one and all will perceive, (re)construct and utilize knowledge in unique-not uniform - fashion. From this perspective, Elias and Merriam (1995) point out that students are encouraged to bring their individuality to each and every learning situation "and in so doing discover or learn whatever is most meaningful" (p. 127) to them.

Just as humanistic theorists espouse relational and self-directed practices of teaching and learning, they also advocate what Rogers designated as "whole person" learning.

Whereas conventional modes of education accentuate rigid behavioral objectives, quantifiable assessment of learning, and objective ways of knowing, humanistic adherents favor approaches intended to encompass the continuity of cognitive/rational and affective/intuitive educative experiences. The crux of Roger's critique, which remains pertinent today, is that the dichotomous privileging of reason over emotion is not only ensconced firmly in mainstream cultural practice, but continues to constrain educational discourse, policy-making and classroom instruction. American education, Roger (1980) declared, has "focused so intently on ideas" that it has restricted itself to "education from the neck up" (p. 267). To the contrary, he posited that the cognitive/rational and affective/intuitive ways of knowing were not only interrelated, but mutually constitutive of the individual's personal growth and sociopsychological development. He observed:

There should be a place for learning by the whole person, with feelings and ideas merged. I have given much thought to this question of bringing together cognitive learning, which has always been needed, and affective-experiential learning, which is so underplayed in education today... So if I were to attempt a crude definition of what it means to learn as a whole person, I would say that it involves learning of a unified sort, at the cognitive, feeling, and gut levels, with a clear awareness of the different aspects of this unified learning. (1980, pp. 264, 266)

Rogers upheld that the diffusion of knowledge from a source to a recipient was "a relatively unimportant and vastly overvalued activity" (1994, p. 151) and proposed that the overarching purpose of education should be the facilitation of learning by means of cultivating necessary and sufficient conditions that encourage transformative, self-initiated and more connected forms of knowing (Patterson, 1977; Rogers, $1961,1969,1980)$. Toward this end, he articulated three classroom attitudes that he reasoned must be present to cultivate growth-promoting conditions. The major emphasis of these attitudinal conditions is on the social, psychological and emotional development of the student, as facilitated by, and through, the teacher-student relationship.

The educator being authentic and present in the moment, "without presenting a front or façade" (Rogers, 1980, p. 271) characterizes Rogers' first condition, realness or congruence. In this sense, the teacher 
enters into learning relationships in a way that allows him or her to forgo the professional rigidity and artificiality of the role and embrace more personal, authentic and immediate connections with students. It also means maintaining mindfulness of what one is experiencing in the moment, welcoming these experiences (e.g., emotions, state of mind, intuitions, convictions) as legitimate and indispensable ways of knowing and understanding oneself, and conveying them when they hold relational import. Thus, from this vantage point:

[W]e see that the teacher can be a real person in her relationship with her students. She can be enthusiastic, bored, interested in students, angry, sensitive, and sympathetic. Because she accepts these feelings as her own, she has no need to impose them on her students... Thus she is a person to her students, not a faceless embodiment of a curricular requirement or a sterile tube through which knowledge is passed from one generation to the next. (Rogers \& Freiberg, 1994, p. 154)

The second condition of the model is what Rogers termed as prizing acceptance, or trust, in others. Characteristic of this attitude is a non-possessive caring for the learner- "an acceptance of this other individual [student] as a separate person, a respect for the other has having worth in his or her own right" (1980, p. 271). It suggests a broad-minded, impartial recognition of the complex, and sometimes incongruous, perspectives, standpoints, and opinions students' have of themselves and their realities, and confirming their right to hold them.

Accordingly, the facilitator "can be fully acceptant of the fear and hesitation of the students as they approach new problems as well as acceptant of the pupils' satisfaction in achievement" (p. 272). This acceptance, observed Rogers, is an operational expression of the facilitator's faith and confidence in the capacity of interactants to make judgements about their own lives, coupled with an unconditional willingness to allow students to experience their realities without fear of reprisal or penalty.

The final condition is empathic understanding. Rogers (1957) defined empathy as perceiving "the internal frame of reference of another with accuracy, and with the emotional components and meaning which pertain thereto, as if one were the other person, and without ever losing the 'as if' condition" (p. 210). Empathic understanding is both a cognitive and affective process, one that affirms the individual as a whole person; specifically, it emphasizes the teacher-facilitator's capacity to (a) assume the perspectives of his or her students (role-taking) and (b) identify with their experiences without prejudice or preconception. Instead of concentrating on evaluative methods of understanding (e.g., understanding as good/bad, right/wrong, correct/erroneous), humanistic educators strive to recognize and accept the learning experiences of students as is. This, in turn, becomes a curriculum resource for supporting and inspiring further forms of self-initiated learning. Rogers (1980) suggested that when the teacher has "the ability to understand each student's reactions from the inside... the likelihood that significant learning will take place is increased" (p. 273).

Given the capacity of humanistic education to facilitate students' emotional, social, and psychological growth and development, the objective of this qualitative project was to examine the way one instructor utilized a humanistic pedagogy to help her university students deal with their communication anxieties in an introductory public speaking course. As such, the following research question was posed:

RQ: In what ways can humanistic pedagogy help college students deal with public speaking anxieties in an introductory communication course?

\section{Method}

WALTON / DOI: 10.5929/2018.8.1.2 


\section{The Participant}

Madilyn Wald (a pseudonym) grew up on a small farm in the Texas panhandle. The third of five children, she was the first in her family to attend college, graduating with a speech/drama education degree in the early 1960s. Having spent 12 years teaching, coaching and directing a small speech and theatre program at a west Texas high school, Madilyn returned to college full time to pursue a graduate degree in counseling psychology. It was during her master's program that she was first exposed to Rogers' work on client-centered therapy and humanistic psychology. For the next 33 years, she worked at various counseling clinics, hospitals and military installations in the South Central region of the United States specializing in marriage and family therapy, post-traumatic stress, and career counseling. Near the end of her professional counseling career, Madilyn picked up a M.A. in corporate communication and began adjunct teaching introductory communication and psychology classes at various community colleges.

At the age of 73, Madilyn chose to come out of retirement to become a full-time instructor of communication studies at my university. At the time, I was serving as the basic course director for our introductory communication course and had the good fortune to work closely with her during her fiveyear stint at our institution. In this short time, Madilyn boasted the highest credit hour production of any full-time faculty member within the department, maintained one of the highest student retention rates within the institution, and pulled superior-level course evaluation scores for 10 successive semesters. Her approach to public speaking pedagogy, as unconventional as it was for university-level instruction, plainly resonated with students as she quickly became, based upon anecdotal evidence from the university's academic advising center, the most requested general education instructor on the campus.

\section{Teaching-Research Situation}

Madilyn's primary instructional assignment was teaching five sections of our basic public speaking course per term. The class, "Fundamentals of Speech," was and continues to be staffed by a combination of fulltime faculty and qualified part-time adjuncts. At the time in which this study was conducted, the official university catalog description of the course read as follows:

COMM 1113 FUNDAMENTALS OF SPEECH: An introductory course designed to acquaint the student with the basic theory and practice of public speaking. The course provides practical experience in the composition and delivery of oral presentations in diverse situations. Topics include speech organization, forms of supporting materials, audience analysis, delivery and critical evaluation of speeches. Lecture 3 hours.

The COMM 1113 curriculum serves three basic purposes: (a) to improve students' oral communication competencies, (b) to attract potential communication majors, and (c) to support the university's general education program. At the time, the department offered roughly 25 to 30 sections of COMM 1113 per semester, taught in both traditional and alternative platforms and delivered in various formats.

Students are responsible for four major speeches, three exams, and a series of instructor-defined quizzes/assignments; of the four speeches, two are informative and two are persuasive. Speech assignments require students to use different topics, organizational arrangements, supporting materials, rhetorical devices, etc. While general course requirements and policies are standardized across all sections and formats, instructors are given flexibility to establish the specific requirements and parameters of individual speaking assignments, customize course assessments and rubrics for projects, and utilize varying instructional models and strategies as long as the course's core learning outcomes are met.

WALTON / DOI: 10.5929/2018.8.1.2 


\section{Data Collection \& Analysis}

A qualitative methodology and interpretive framework were utilized to gather and analyze the data. Procedurally, I approached this inquiry as a type of intrinsic case study, which Stake (1995) explains as an in-depth examination of a case where the case itself is of unique interest or value. Specific methods for data collection included open-ended interviews with the participant, classroom observations, content analyses of students' course evaluations and regular reflection and collaboration with the participant (Creswell, 2005). Over the course of her five years in the department, I conducted approximately 10 openended, conversational interviews with Madilyn in the privacy of her campus office. As defined by Lindlof (1995), interviews are events "in which one person (the interviewer) encourages another person to articulate interests or experiences freely" (p. 163). These in-depth interviews, usually lasting one to two hours in length, allowed me to delve deeply into her instructional approach and explore connections between her philosophy of education and classroom pedagogy. Interviews were digitally recorded and transcribed, and fieldnotes taken of my reflexive observations of each session (Rubin \& Rubin, 2012). From the outset of our professional relationship, the two of us shared a strong degree of interpersonal rapport, which put both of us at ease during our interviews and helped me elicit the kinds of information relevant to this study's purposes.

By virtue of my position as basic course director, I was required to evaluate Madilyn's teaching performance at least once per term. Recognizing my interest in her interpretation of the curriculum, she graciously extended me an open-ended invitation to visit her classes at my discretion-an offer, parenthetically, I gratefully accepted. In total, approximately 18 hours of field observation were made from fall 2010 to spring 2015. As with our interview sessions, fieldnotes were taken during and immediately after each class meeting. The extent of my involvement in her class sessions was limited in order to preserve the spontaneity and emergent structure of each class gathering.

Student feedback collected through Madilyn's end-of-semester course evaluations provided an additional data source. Of particular interest were the open-ended, qualitative comment questions that queried learners about the strengths and weaknesses of the class, the instructor's management of the course, perceived forms of learning, and overall level of satisfaction with the class.

Identification of thematic categories and properties was based upon Creswell's (1998) data analysis model that was used to arrange, classify, and illuminate the findings. The process opened with an initial categorization of the content and spiraled up through conversion, examination, theoretical note-taking, and the interpretation of findings. The steps included: (a) creating topical categories of specific quotations or observations that were independently relevant to the phenomena of interest, (b) classification of topical categories into units of meaning, (c) reflection upon emergent categories to determine possible meanings and frames of reference for the phenomenon, and (d) constructing a descriptive summary of the overall experience (Creswell, 1998). In the analysis of these data, I attempted to identify general themes as they materialized, moving from broad topical classifications to the development of specific conceptual categories. Ultimately, three major and interrelated themes were derived, which became the basis of this report.

\section{Findings}

Analysis of data yielded three basic findings regarding Madilyn's public speaking pedagogy: (a) supporting the expression of feelings and emotions, (b) prizing the whole student, and (c) encouraging intrinsic motivational learning. Each of these themes will be discussed in turn.

Supporting the Expression of Feelings and Emotions

WALTON / DOI: 10.5929/2018.8.1.2 
Madilyn recognized that she had content to cover and that there were department-level expectations that she would teach the skills, techniques and proficiencies associated with what the communication discipline considers competent public speaking performance (Morreale \& Hackman, 1994; Morreale, Rubin, \& Jones, 1998). Even so, for her, this focus was plainly a secondary matter: "A great deal can get lost in the x's and o's and if you're not careful, the content becomes more important than the lives in that classroom." She proposed that an emotionally sterile approach to public speaking pedagogy failed to address adequately the fears and vulnerabilities that underlie the foundation communication apprehension:

I don't want them [students] to suppress their emotions or to pretend they don't matter, because they really do. Suppression becomes a barrier and can wreck an oral presentation. If I'm going to teach public speaking, I'm going to teach all of it - the subject and idiosyncratic characteristics that come with it.

Balancing content and emotionality was uncomplicated for Madilyn. Although she aimed to cover the formal curriculum of the class, she recognized that this did not necessarily impede her from addressing students' emotional states or anxieties about public speaking. Throughout her classes, she utilized a variety of exercises, some of which were entirely unexpected and unplanned, to help students identify, locate, and name emotional expressions or reactions that they found inimical to their public speaking achievements. For example, Madilyn opened one classroom exercise by asking students to write down a list of activities they partake in where they typically feel safe and secure:

I ask them to pinpoint events and situations where they feel naturally comfortable and confident in what they are doing. Then I ask them why they feel that way. The answers are not that surprising to me, but it opens conversation. A lot of it deals with control and what they have some control over-control over their expectations, their actions, bodies... they have confidence in themselves to let go and perform. The activity is gratifying to them because they know what's going on, they feel safe, and aren't overthinking it.

After students derived a working list, she asked them to pinpoint circumstances where they feel overwhelmed by a task or which trigger insecurities about themselves. Via class dialogue, she pointed out remarkably similar commonalities in their answers:

You'll hear them talk about uncertainty, the fear of being judged, or looking inept, or not knowing what to do. A lot of it is about external locus of evaluation...they allow the judgements of others to dominate their self-perceptions and it shuts them down. When they are responding to the evaluations of the others, they lose focus on themselves. It is like they lose control and become powerless and can't execute... as if they are restrained by the situation. And so asking, "what will others think of me?" is the sole measure of their successes and their failures.

Thus, Madilyn helped her students clarify the differences between internal and external locus of evaluation, and how destructive perceptions of inadequacy can be when one becomes reliant on the approval of others. This bit of self-knowledge appeared to engage students in a way that made them more cognizant of negative experiences and seemed to provide an opportunity for them to reflect on the importance of acquiring growthful attitudes and personal definitions of success. Occasionally, changes in mindset and perspective were immediate; more often, however, they were constructed progressively as students were encouraged to reflect upon and reconcile their public speaking histories with present-day experiences.

WALTON / DOI: 10.5929/2018.8.1.2 
Through exercises like these, Madilyn pushed her students to recognize and encounter their feelings as they emerged in the class. Following each major presentation, she requested that students journal on their emotional wellbeing-about themselves, major assignments, the class, etc. - and to use descriptive language (e.g., metaphors, idioms), when appropriate, to convey them. At the conclusion of the semester, students were to revisit their journal entries and to note any remarkable or curious patterns in their emotional work. This level of introspection, she maintained, supplemented students' experiential learning with an informative degree of self-realization and constructive self-expression: "It is a way of growing their emotional intelligence, which is a large part of having an inner presence of self."

Madilyn also practiced what she called "venting," short for ventilation. By this, she meant that students were always welcome to share their opinions, feeling, ideas and frame of mind on anything courserelated. "All students have to say is, 'I need to vent!' and I let them air whatever is on their minds." On several occasions, I witnessed first-hand how these venting opportunities worked and how successful they were at developing a sense of care and camaraderie within the classroom environment. In one instance, a student remarked that he was "irritated and confused" about his speech outline and accompanying research. Almost immediately, four or five of his peers submitted similar supportive concerns. In another situation, a student verbalized trepidation about the length requirement of the second public speaking assignment; once again, her classmates voiced comparable fears. "My emotional vent sessions have two uses behind them," Madilyn stated. "First, my students recognize that they are not unaccompanied. Bruce is not the only person in the classroom experiencing this feeling or this question. Others are also worried about this or that." And secondly, "I suppose it legitimizes having and owning those feelings. Everyone has them and everyone encounters them. The key is handling them [emotions] to learn about oneself." Hence, as was clear, Madilyn's overarching approach was designed to lead to a greater identification with others, as well as endorse a deeper understanding of self within a specific communicative context. From a humanistic perspective, this reinforces the belief that learning is a wholistic and systemic process that encompasses and draws upon rational and emotional/intuitive domains of knowledge.

Madilyn was very mindful of the fact that emotions were not stagnant, but ever changing, and urged her students to share and reflect upon their fluctuating qualities:

One day something seems to make sense and the next day, you're absolutely confounded or disturbed at the thought of it. I've had a lot of those moments over the years. Then, after we talk about it some more, the student is comfortable with it again and regains confidence. We've all been there before and it's a part of attending to one's defenses and fears. I've had students actually lose confidence after their first speech and I had clients lose confidence in themselves after a counseling session or two. Seems absurd, but it can happen and can be a learning opportunity. I will often ask them why they have had the change in feelings... what has happened or going on within their perspective.

Emotional expression was not always negative or downbeat. In reality, Madilyn perceived that many of the remarks were quite optimistic and noted that the amount of positive disclosures frequently increased as the semester advanced. She took this as evidence of students' budding self-confidence and emerging level of self-efficacy.

Exercising what Rogers called "congruence," Madilyn pointed out that she, likewise, made her feelings and emotional states known to her classes:

If I'm exhausted or having a particularly good or bad day, I try to convey that right at the start. I may not be in the right state of mind to grades speeches that day. There is nothing improper or

WALTON / DOI: 10.5929/2018.8.1.2 
unethical about divulging that information...it's called sincerity and authenticity and being human... If I'm extraordinarily pleased or disappointed with a [class] period, I'Il let them know.

In this manner, Madilyn modeled for her students a willingness to acknowledge-rather than neglect or suppress-her emotional perspectives and take into consideration ways her thought processes influenced her instructional performance and decision-making: "I want to be a real person to them, not a mechanism through which the institution manages them. I let them know what I'm brooding over. Sometimes it isn't very nice, but it is genuine." She also exhibited taking responsibility for her emotions and using them as a means for self-examination:

I have them, I possess them, and I reflect on them... The key question is getting students to consider "why am I feeling this way today, at this moment,"? If you display some of this in the classroom, verbally, they can see how valuable it can be.

In short, Madilyn's desire to endorse and encourage emotional/intuitive ways of knowing appeared to empower herself as well as her students. Rather than offer a traditionally sanitized public speaking curriculum, Madilyn spoke candidly with her students about their communication anxieties and sought to promote continued emotional growth based upon their heightened empathy and self-awareness. By offering reassurance and allowing her pupils to exercise their emotional intelligence, she presented yet another important layer of compassion so critical to assuaging the anxieties associated with public speaking: "if we only teach tried and true textbook techniques of public address, we are turning our backs on $50 \%$ or more of the problem. I can study aviation all day but that doesn't necessarily soften my fear of flying on an airplane."

\section{Prizing and Valuing Students}

Madilyn considered affirmation messages and positive regard critical components of her pedagogy. Reminiscing on her graduate training, she paraphrased a definition of the term "respect" that had remained with her for over 30 years: "respect, if I think of it properly, suggests seeing people as people, not as categories, or labels, or stereotypes, and appreciating them because they are alive." Whereas many teachers strive to maintain a dispassionate professional division between themselves and their students, Madilyn actually looked for opportunities to lessen that distance so that she could better understand and adjust to their needs, fears and goals.

Positive regard was exercised in myriad ways. For example, at the beginning of each term, Madilyn made clear her role in the class and espoused her staunch support for every student she taught:

I want them to know that I am rooting for them and not against them. Everyone in my class can succeed and I'll do my best to help them. All of us have things we can work on and get better at but we need encouragement and guidance along the way. I see my job as doing those things.

To make her point, she disclosed a personal account to her students about a time in her teaching career when she worked under a school principal that she insisted "wanted her to fail." The point of the story was that she recognized how crestfallen one can be when an authority figure fails to appreciate one's potential. In contrast, she was wholly devoted to acknowledging and confirming everyone's talents and capacities:

It is a big part of creating trust and reassurance with your students. They need to know that I am with them and not against them. If they feel this way they are more likely to take risks without fearing me or what I might say. Progress, I think, is linked to the climate of your relationship.

WALTON / DOI: 10.5929/2018.8.1.2 
Given the amount of trepidation surrounding the public speaking course-particularly the evaluation (e.g., grading) of one's public speaking abilities-Madilyn felt it important to honor students' current skill-level as a way of reinforcing her respect and support for class members. In being attentive to students' existing interests and talents, she imparted an awareness about their individuality that appeared to put many at ease:

I find little things that each one of them does well, they speak clearly or have a pleasant-sounding voice or have a strong nonverbal presence, and really emphasize it. And I try to tell them that they have something that they can build off of if they want to do so. I want them to know that I am paying attention to them and actually realize how much work they are doing. I don't like the idea of filling up a speech critique sheet with negative remarks. I don't put negative remarks.

Apparently, on this very point, one student remarked:

Madilyn wasn't ever discouraging about our speech performances like I hear other teachers are. She is very positive and helpful. She helps you by telling you what you did right. I didn't feel uncomfortable speaking as I thought I would because she is not looking to nail you.

As Rogers (1980) posited, "attending" is, itself, a means for signaling or denoting respect and regard for others. Thus, Madilyn's use of attending cues, both verbal and written, demonstrated curiosity and interest in her learners and re-affirmed her support for their continued growth and development. Several students, in fact, commented on the amount of care and attention she bestowed onto them:

Madilyn is the only college professor I have had who genuinely cares about her students. She pays close attention to us and wants us to do our best. She notices everything... She doesn't focus on what we do for mistakes but what we do right.

Another observed:

She is a tremendous instructor! She is very caring and compassionate about us and is never mean or cruel. She makes it possible for us to succeed in her class even if we are scared to death of speaking in front of other people. I overcame my fear of public speaking because of her support and sensitivity... She grins the whole time you give your speech!

Much in the same way, Madilyn incorporated verbal praise and compliments into virtually every aspect of her instruction. Whether it was in regards to a question asked by a student, a provocative comment made during a class discussion or someone volunteering to assist her with the technology in the classroom, she took the time to publicly recognize and thank them for their contributions. This, of course, extended to her public speaking exercises as well where a common refrain was "Thank you for words and wisdom." It is difficult to know how or if these comments influenced students' oral performances, but they did impart a sense of gratitude and enthusiasm for their efforts. Madilyn explained: "If they know that their participation is wanted and welcomed, they will be more likely to get involved. They need to know that their voices and actions are cherished because they are in my classroom."

Madilyn recognized other methods for respecting and endorsing her students, as well. A memorable discussion was her approach to teaching the concept of "speaker credibility" and using it as a vehicle for honoring students' prior interests and experiences. In the course textbook, The Art of Public Speaking, communication professor Stephen Lucas (2015) depicts credibility as "the audience's perception of whether a speaker is qualified to speak on a given topic. The two major factors influencing speaker's credibility are competence and character" (p. 333). Madilyn brilliantly interpreted and applied this 
definition to emphasize the knowledge, talents, and experiences students brought with them into the classroom:

I tell them that they are all intelligent creatures and have expertise in something. Bobby knows all there is to know about computers, Tim is exceptional at horseback riding, Linda is a virtuoso at the piano, Karla loves politics, Mary has a thing for musical theatre. I have them make a list of all the topics that know something about and I have them share these with their classmates. Then I tell them that we have the makings for some outstanding speeches in the class based on all this familiarity and expertise.

Rather than using preset speech topics or foci, Madilyn extended her students broad discretion in selecting issues of which they were interested and/or presently conversant. She believed that this degree of latitude not only connected the public speaking curriculum with previous learning, but also honored their personal interests and insights. She explained:

It is better than starting out at ground zero and making them pick topics they absolutely know nothing about. That can make the fear even worse. I try to teach public speaking with context and regard [for students' prior experiences]. I let them apply their level of expertise to our assignments as opposed to than telling them that none of that matters. We can make any topic work and fit [the public speaking assignment]... but I always try to respect their choices. I never liked the idea of the teacher telling students that their ideas were poor or stupid.

Prizing and recognition were essential parts of Madilyn's pedagogy as it denoted a key shift from teachercenteredness to student-centeredness. Based on the data available, students appeared appreciative of this level of endorsement and encouraged by her frequent and explicit use of supportive communication. Her consistent use of prizing messages engendered constructive student responses, which, in turn, helped them remain immersed in the learning process and more engaged with course material. Not only was she receptive to a full range of student interests and experiences, the affectively safe relations she nurtured in her classes also encouraged peer acceptance and identification with diverse others.

\section{Nurturing a "Motivation to Learn" About Public Speaking}

Education and communication scholars alike have sought to understand students' motivations to learn, often by inspecting the reasons or bases for their learning. Of the various facets associated with human motivation, the topics of internal (intrinsic) and external (extrinsic) motivation have received the most academic attention. Generally defined, internal motivation refers to the self-directed desire or propensity to learn something for its own sake, whereas external motivation refers to learning that is driven as a means to a pre-selected end (Ryan \& Deci, 2000). Proponents of humanistic education have historically emphasized intrinsic sources of learning, such as self-determination, autonomy and striving for personal well-being and growth (Combs, 1981; Combs et al., 1974; DeCarvalho, 1991; Hamacheck, 1987; Morris, 1978; Rogers, 1969; Sage et al., 2012; Valett, 1977).

Throughout her teaching and counseling careers, Madilyn pursued avenues for supporting and reinforcing intrinsic practices of motivation: "I believe that honest change comes from the inside and that learning occurs best when it is self-inclined... because a person wants to genuinely improve themselves." Teaching public speaking was particularly challenging in this regard given the performative, and thus, productiondriven nature of the course. "Most approach this class from a condition of fear and hope to muster up the guts and strength to get up in front of the audience a few times, get a passing grading, and stay alive," she stated. "I don't find that particularly useful because it is inhibiting and there is so much more to it [oral communication education] than that."

WALTON / DOI: 10.5929/2018.8.1.2 
In many respects, Madilyn approached the Fundamentals of Speech course from a life-skills perspective, reasoning that the class offered extensive benefits to students' personal lives and professional ambitions. "The key to it," she surmised, "is getting them to see it that way."

One way Madilyn attempted to cultivate intrinsic learning was to connect the course to students' current and future objectives. Alternating among examples, she utilized a number of employer surveys that listed "communication skills" as a top skill target for future employees. This, she believed, helped contextualize the real-world value of the subject and role it could play in securing employment opportunities after graduation. She stated:

It's not the best reason to sell this class, but I think it can work... I explain to them that all of us have oddities when it comes to communicating and that sometimes these challenges prevent us from getting a job or could get us canned. Then we discuss the pros of the class, you know, what it could do for them in getting a job and what areas it could benefit them. We discuss interviews, professional presentations, poise, and things like that.

Supplementing this discussion, Madilyn asked students to identity personal habits or idiosyncrasies that they may hold which might deleteriously affect them in a career field or potentially preclude them from getting a good job. "After they recognize a few," she stated, "I discuss how taking a Fundamentals of Speech course might address those concerns. It helps them connect the dots and see the class beyond just a general education requirement. It's another way of peddling it to them."

As previously detailed, Madilyn also strived to relate course content to students' personal wellbeing. By focusing on measured improvement rather than flawlessness, Madilyn was able to emphasize the incremental and developmental nature of communicative learning. On the first day of each new term she established the groundwork for her expectations:

It's a little talk I started giving years ago when I was doing family therapy. I tell them that I've never in my life heard a perfect speech and that I won't hear one in this class. There is no such thing as a perfect presentation. I tell them that I am not a perfect speaker or teacher and that I've never delivered a perfect speech or taught a perfect class in my entire life. All of us have room for improvement, but none of us are perfect. To some extent, perfection is relative. I've always felt like it takes the pressure off of performing and lets them know I'm focused on them improving, not on grades.

Based upon my class observations, this "little talk" helped dissipate some students' sense of anxiety by removing the comparative and evaluative pressures associated with traditional performance-based assessment. Consider, for example, this student's end-of-semester comment: “Ms. Wald didn't put tons of stress on us to give seamless speeches. She understood that I was new at it and scared and encouraged me to get as good as I thought I could get in a semester." Another wrote, "we weren't in competition with each other over who gave the best speeches.

There was no pressure to outperform or show up anyone." Interestingly, Madilyn also declined to share sample speeches (e.g., textbook demonstrations, previous student work) with her pupils, as she believed it unduly pressured them to duplicate other students' work:

I realize a lot of you do [other instructors], but I don't show them. I don't want them to try to be like somebody else. I don't want them to think, "That is the public speech she thinks is perfect and that I need to emulate to pass this class." I've never like the idea of showing sample speeches because it pressures them to compare themselves against an external standard and to see their 
success or failure from that standard. I wouldn't want a married couple to identity a perfect TV family and then try to be that family and then regard themselves as a failed experiment when they find they can't live up to it. Then failure is seen an incapacity to mimic what someone else is doing. It's like saying to a kid, "I want you to be creative by copying what someone else did.

Madilyn used a combination of small group exercises, concept mapping techniques and reflective activities to encourage meaningful ties between course material and everyday contexts. For example, halfway through the semester, she would assign students a take-home letter with the following guidelines:

Imagine it is 5 years into the future. Reflecting on what you've accomplished in the class thus far, write your "past self" a one-page letter telling yourself what you wished you had learned in your Fundamentals of Speech class all those years ago.

Madilyn believed that activities such as this encouraged students to appreciate public speaking instruction and gave them a greater comprehension for the long-term value of communication education.

Another way Madilyn attempted to model intrinsic motivation was through the sharing of personal narratives. On multiple occasions, both publicly and privately, Madilyn exhibited her passion for the course by revealing personal testimony about ways the course had encouraged previous students, including herself. One account of interest was about a man who had recently approached her at a local restaurant:

So, I'm sitting there eating solo and look up and this grown man is standing there smiling at me. I ask if I could help him and he says, "You already have." He reminds me who he is and what year he took my introductory speech class and tells me how it essentially changed his life... and all these things he has done with his career... became a manager and regional vice president I think he said, because of the self-confidence and composure he gained in my class. Then he hugs me and walks away. It was absolutely the best compliment a teacher could get!

"I've got a few [stories] like that that I share from time to time," Madilyn remarked. "It helps them see the value of the class from someone else's perspective. I use them whenever I think they need them." Likewise, she openly communicated her own interest and passion in the subject matter:

I talk about how I got into speech and drama when I was younger and what we used to call language arts and all that it did for me personally. It helped me $110 \%$ in my counseling job and made me a better listening and communicator and, of course, a better instructor. I am forever grateful to my teachers for introducing me to communication. I did some drama in my high school but when I went to college I had not a penny to my name and no idea what I wanted to do in my life. My classes in drama and speech and psychology helped me find my career and myself. I became, I would say, a more confident woman because of it.

Hence, through the sharing of these accounts, Madilyn tried to convey her enthusiasm for learning and teaching communication, as well as demonstrate real-life instances in which the public speaking course had helped enrich prior students' lives.

Lastly, to keep her pupils focused on self-directed methods of personal growth and development, Madilyn employed a version of mastery learning for all major class presentations. As defined by her, mastery learning meant allowing students multiple opportunities to present a speech until they were personally satisfied with their performance. It was only then that they were allowed to move on to subsequent projects. Rebuffing the opinion that all students should advance through the course on approximately the 
same timetable, she offered pupils considerable flexibly regarding their readiness to move into progressively more difficult work. From my standpoint, this was one of the more bothering facets of her pedagogy as it put her courses on, what I perceived as, an impossible calendar for covering required content. As evidenced, in a handful of her course evaluations, this concern also resonated with a few students:

"Ms. Wald's class was always running behind schedule and I never knew what we were doing that day. We had someone speaking almost every single day of the semester."

"Half the class is still on the first informative speech while half is moving on to the first persuasive speech. This is unfair in my opinion and a chaotic way to teach a class like this."

Yet again, Madilyn was undeterred by these criticisms. She argued that a mastery-based process was important for students' growth and made them more cognizant of their goals and developmental progress. "I want them to know that we all have room for improvement and that we can continue to grow and pull through our experiences," she remarked. Madilyn also used mastery learning to diminish fears about public speaking:

Part of the fear is that they [students] have one shot to do this speech and if they bomb it, it will ruin their grade. That causes fear and panic, very simple. Imagine being $100 \%$ terrified of doing something and then getting one and only one shot at doing it and getting graded on it. I don't teach my courses that way.

This is not to suggest that Madilyn did not take grades seriously. Indeed, she did and found considerable value in providing students with substantive, formative feedback. However, rather than privileging her evaluations of their work, she was interested in the way her students' perceived their own efforts and encouraged self-defined standards for assessing their own progress:

If a student wants to re-do a speech, they must first write me a short reason as to why. Why do they want a re-do? Why do they think the do-over will be better than the first? What did they learn from the first project? What did they learn from my feedback? How are they changing their speech? For them, what is success? These are the things I want them to think about. Everyone is different, absolutely.

True to her commitments to humanistic education, her use of personal journals, one-on-one student meetings and class discussions gave strong indication of the type of classroom environment she hoped to cultivate. Among other things, connecting the course to students' needs and goals, exhibiting her personal appreciation for communication education, and re- directing students' attention to meaningful, selfdetermined learning goals appeared to play positively in assuaging many of her students' public speaking anxieties.

\section{Limitations of the Approach}

In spite of its purported impact on student learning, there were clear limitations to Madilyn's pedagogy and thus warrant acknowledgement. First, a common criticism of Madilyn's instructional approach, which often surfaced in her end-of-term course evaluations, was the claim that her classes were too unplanned and effusive for university-level coursework. Her relaxed, student-centered, "speak-your-mind" approach-which contrasted with the majority of other general education classes offered on the campus - was off-putting to some students, many of whom felt like course content was sacrificed in favor of individual storytelling and group activities.

WALTON / DOI: 10.5929/2018.8.1.2 
A second limitation pertained to course standards and assessment practices. Given her pedagogical approach, class grades were largely de-emphasized as many of her assignments were recorded as satisfactory or unsatisfactory, and multiple opportunities were offered for students to reschedule or resubmit work. Consequently, Madilyn's grade distribution was heavily skewed toward higher letter grades, which she acknowledged might be interpreted as a lack of rigor in her teaching. "I am guilty, I suppose, of some degree of grade inflation, but my assessments are based on the student's growth and not external measuring sticks," she countered. "I think constructive feedback is more effective than punitive grading."

A third reservation relates to the overall effectiveness of the approach in reducing communication apprehension. Since no measures of communication apprehension or public speaking reticence were officially administered, there is no way to quantitatively verify or corroborate the efficacy or long-term implications of her instructional strategy. Toward this end, approaches such as the one featured in this report would undoubtedly benefit from additional empirical support and validation. It is recommended that future instructional research into approaches like the one represented in this report incorporate more direct assessments (i.e., pre- and post-testing) so that comparative (numeric) data may be gathered to substantiate the efficacy of the findings.

\section{Summary and Implications}

The purpose of this qualitative case study was to explore the way one communication teacher dealt with issues of student reticence in her university public speaking courses through the application of humanistic, student-centered principles. Three themes related to her pedagogy emerged from the study: (a) supporting the expression of feelings and emotions, (b) prizing the whole student, and (c) encouraging intrinsic motivational learning. These findings offer several implications for communication teachers and scholars.

First, the findings shed important light on the philosophical and pedagogical dimensions of the introductory public speaking course. At minimum, this analysis provides additional support for Sellnow and Martin's (2010) recommendation that more research be conducted on varying approaches to the teaching the basic course. The process-product paradigm, which has informed a considerable amount of instructional communication scholarship, has largely cast the teacher-student relationship in terms of determining which instructional techniques/methods best maximize pre-defined indicators of student achievement. More recent work, however, predominantly from critical communication scholars (e.g., Alley-Young, 2005; Cooks, 2010; Fassett \& Warren, 2007; Hendrix, Jackson, \& Warren, 2003; Sprague, 1992, 1993; Warren, 2010), has highlighted the limitations of the paradigm and given much needed consideration to a host of socio-communicative phenomena that likewise affect the teaching and learning context. The humanistic approach, such as the one characterized in this report, similarly marks a sharp departure from traditional communication pedagogy by dedicating generous attention to the developmental needs, interests, and personal histories of individual students. Illustrations from this study clearly demonstrate that multiple approaches exist for teaching the basic communication course.

Future work should consider the purposes, teaching practices and content/curricula of the basic course from alternative perspectives and models. Central to this is an understanding of the way knowledge production and student learning are conceptualized by different theoretic positions. As evidenced in the present study, Madilyn saw the basic course as a lived and situated expression of students' capacities, growth and social development; in other words, relationality, not measurability, facilitated her interpretation of student learning and progress. Other schools of thought, however, would undoubtedly frame the discursive features of the course differently, offering other justifications and indicators for 
communicative learning, curriculum development and teaching-learning processes. How, for example, might existentialism inform the structure of the basic communication course or other general education classes? By what means might communication apprehension be described and/or addressed from a postmodern or social behavioral perspective? Such questions, I submit, are key to broadening our theorizing of instructional communication research and developing a more comprehensive philosophy of communication education.

Second, the findings offer qualified support for previous research that has demonstrated the importance of relational messages in establishing positive classroom climates (e.g., Frisby \& Martin, 2010; Frymier \& Houser, 2000; Goodboy \& Myers, 2008; Kougl, 1980; Myers, 1995; Rosenfeld, 1983; Sidelinger \& BoothButterfield, 2010). Frymier and Houser (2000), for example, found teachers' use of communication style and immediacy behaviors to serve as significant predictors of students' affective learning and ego support (i.e., motivation, encouragement). Likewise, Ellis (2000) discovered teacher confirmation behaviors, which are conceptually defined as the processes by which "teachers communicate to students that they are valuable, significant individuals" (p. 265), to play a "large, significant role in college students' cognitive and affective learning" (p. 286). Similarly, drawing off Gibb's work on supportive and defensive climates, Rosenfeld (1983) concluded that "liked" and "disliked" college courses were differentiated by perceived levels of instructor supportiveness.

In the present study, constructive influences on student learning presumably encompassed teacher confirmation and empathy, affirmation of individual interests and emotions, and teacher immediacy. Given these influences, it is reasonable to assume that Madilyn's campus standing and high teaching evaluations were largely a function of the relational culture she cultivated through her instructional approach. While precise methods and approaches would differ from class to class, communication educators are encouraged to examine other similar possibilities for constructing safe and supportive learning environments, particularly in those situations where communication apprehension may be a pivotal factor (Kougl, 1980).

Finally, in line with extant research on communication apprehension, these findings should be interpreted as widening, rather than supplanting, current treatments for communication anxiety. As no single method or approach is sufficient for treating all cases of communication apprehension-public speaking related or otherwise-and no process is without inadequacies, it is critically important that communication teachers and scholars remain committed to broad-based experimentation and study in this area. Because each individual student case is unique in its own right, Dwyer (2000) points out that a multifaceted approach for remedying high communication apprehension cases would likely prove most effective. One advantage of the approach described herein is the degree of care and classroom camaraderie that it fostered against a backdrop of individual fear and anxiety. Hence, these findings have significant consequences for the broader domain of communication apprehension research as they give emphasis to the relational nuances of the construct. An instructional method predicated on themes of mutual understanding, emotional safety, and reflective inquiry would unquestionably enlarge conventional parameters and make noteworthy contributions to the extant literature.

Indeed, Madilyn's humanistic approach to public speaking instruction had significant purpose and value for her students. Based on the findings of this report, I recommend communication teachers consider the benefits of such a framework in their own work and build upon messages that increase the likelihood of establishing caring and respectful relationships, support affective safety and risk-taking and affirm opportunities for personal expression and psychological growth. Regardless of subject matter, Rogers (1980) emphasized that personal learning and social growth are most successfully promoted within safe

WALTON / DOI: 10.5929/2018.8.1.2 
and supportive learning environments. If we are to help our students overcome their communicative fears, no matter the cause or the context, we must continue to search for meaningful and effective ways of helping them confront and grow through their anxieties. Given the outcomes of this study, I submit that humanistic education represents one such possibility.

\section{References}

Allen, M., Hunter, J. E., \& Donohue, W. A. (1989). Meta-analysis of self-report data on the effectiveness of public speaking anxiety treatment techniques. Communication Education, 38(1), 54-76.

Alley-Young, G. (2005). An Individual's Experience: A Socio-Cultural Critique of Communication Apprehension Research. Texas Speech Communication Journal, 30, 36-46.

Ayres, J., \& Hopf, T. S. (1987). Visualization, systematic desensitization, and rational emotive therapy: A comparative evaluation. Communication Education, 36(3), 236-240.

Combs, A. W. (1981). Humanistic education: Too tender for a tough world? The Phi Delta Kappan, 62(6), 446-449.

Combs, A. W., Blume, R. A., Newman, A. J., \& Wass, H. L. (1974). The professional education of teachers: A humanistic approach to teacher preparation (2nd ed.). Boston, MA: Allyn and Bacon.

Cooks, L. (2010). The (critical) pedagogy of communication and the (critical) communication of pedagogy. In D. L. Fassett \& J. T. Warren (Eds.), The Sage handbook of communication and instruction (pp. 293-314). Thousand Oaks, CA: Sage Publications.

Creswell, J. W. (1998). Qualitative inquiry and research design: Choosing among five traditions. Thousand Oaks, CA: Sage.

Creswell, J. W. (2005). Educational research: Planning, conducting, and evaluating quantitative and qualitative research. Upper Saddle River, NJ: Merrill.

Cronin, M., \& Glenn, P. (1991). Oral communication across the curriculum in higher education: The state of the art. Communication Education, 40(4), 356-367.

DeCarvalho, R. J. (1991). The humanistic paradigm in education. The Humanistic Psychologist, 19(1), 88.

Dwyer, K. K. (2000). The multidimensional model: Teaching students to self-manage high communication apprehension by self-selecting treatments. Communication Education, 49(1), 72-81.

Dwyer, K. K., \& Davidson, M. M. (2012). Is public speaking really more feared than death? Communication Research Reports, 29(2), 99-107.

Elias, J. L., \& Merriam, S. B. (1995). Philosophical foundations of adult education. Melbourne, FL: Krieger Publishing Co.

Ellis, K. (2000). Perceived teacher confirmation. Human Communication Research, 26, 264-291.

Fassett, D. L., \& Warren, J. T. (2007). Critical communication pedagogy. Thousand Oaks, CA: Sage Publications.

Frisby, B. N., \& Martin, M. M. (2010). Instructor-student and student-student rapport in the classroom. Communication Education, 59(2), 146-164.

Frymier, A. B., \& Houser, M. L. (2000). The teacher-student relationship as an interpersonal relationship. Communication Education, 49, 207-219. 
Goodboy, A. K., \& Myers, S. A. (2008). The effect of teacher confirmation on student communication and learning outcomes. Communication Education, 57(2), 153-179.

Hamacheck, D. E. (1987). Humanistic psychology: Theory, postulates, and implications for educational processes. In J. A. Glover (Ed.), Historical foundations of educational psychology (pp. 159-182). New York: Plenum.

Hendrix, K. G., Jackson II, R. L., \& Warren, J. R. (2003). Shifting academic landscapes: Exploring coidentities, identity negotiation, and critical progressive pedagogy. Communication Education, 52, 177-190.

Hopf, T., \& Ayres, J. (1992). Coping with public speaking anxiety: An examination of various combinations of systematic desensitization, skills training, and visualization. Journal of Applied Communication Research, 20(2), 183-198.

Kelly, L., \& Keaten, J. A. (2000). Treating communication anxiety: Implications of the communibiological paradigm. Communication Education, 49(1), 45-57.

Kougl, K. M. (1980). Dealing with quite students in the basic college speech course. Communication Education, 29, 234.

Lindlof, T. R. (1995). Qualitative communication research methods. Thousand Oaks, CA: Sage.

Lucas, S. E. (2015). The art of public speaking (12th ed.). New York: McGraw-Hill.

McCroskey, J. C. (1977a). Classroom consequences of communication apprehension. Communication education, 26(1), 27-33.

McCroskey, J. C. (1977b). Oral communication apprehension: A summary of recent theory and research. Human communication research, 4(1), 78-96.

McCroskey, J. C. (1984). The communication apprehensive perspective. In J. A. Daly \& J. C. McCroskey (Eds.), Avoiding communication: Shyness, reticence, and communication apprehension (pp. 1338). Beverly Hills, CA: Sage.

McCroskey, J. C., Daly, J. A., \& Sorensen, G. (1976). Personality correlates of communication apprehension: A research note. Human Communication Research, 2(4), 376-380.

Morreale, S. P., \& Backlund, P. M. (2002). Communication curricula: History, recommendations, resources. Communication Education, 51, 2-18.

Morreale, S. P., \& Hackman, M. Z. (1994). A communication competency approach to public speaking instruction. Journal of Instructional Psychology, 21, 250-258.

Morreale, S., Rubin, R. B., \& Jones, E. (Eds.). (1998). Speaking and listening competencies for college students. Washington, DC: National Communication Association.

Morris, J. (1978). Psychology and teaching: A humanistic view. New York: Random House Myers, S. A. (1995). Student perceptions of teacher affinity-seeking and classroom climate. Communication Research Reports, 12, 192-199.

Patterson, C. H. (1977). Foundations for a theory of instruction and educational psychology. New York: Harper \& Row.

WALTON / DOI: 10.5929/2018.8.1.2 
Richmond, V., \& McCroskey, J. C. (1998). Communication: Apprehension, avoidance, and effectiveness. (5th ed.). New York: Allyn \& Bacon.

Robinson, T. E. (1997). Communication apprehension and the basic public speaking course: A national survey of in-class treatment techniques. Communication Education, 46, 188-197.

Rogers, C. R. (1959). A theory of therapy: Personality and interpersonal relationships as developed in the client-centered framework. In S. Koch (Ed.), Psychology, a study of science: Foundations of the person and the social context, Vol. 3 (pp. 184-256). New York: McGraw-Hill.

Rogers, C. R. (1969). Freedom to learn. Columbus, OH: Merrill.

Rogers, C. R. (1980). A way of being. New York: Houghton Mifflin.

Rogers, C. R., \& Friedberg, H. J. (1994). Freedom to learn (3rd ed.). Columbus, OH: Merrill-MacMillan.

Rogers, C.R. (1961). On becoming a person. Boston, MA: Houghton Mifflin.

Rosenfeld, L. B. (1983). Communication climate and coping mechanisms in the college classroom. Communication Education, 32(2), 167-174.

Rubin, H. J., \& Rubin, I. S. (2012). Qualitative interviewing: The art of hearing data (3rd ed.). Los Angeles, CA: Sage.

Ryan, R. M., \& Deci, E. L. (2000). Intrinsic and extrinsic motivations: Classic definitions and new directions. Contemporary educational psychology, 25(1), 54-67.

Sage, S. M., Adcock, S. S., \& Dixon, A. L. (2012). Why humanistic teacher education still matters. Action in Teacher Education, 34(3), 204-220.

Schreiber, L. M., Paul, G. D., \& Shibley, L. R. (2012). The development and test of the public speaking competence rubric. Communication Education, 61(3), 205-233.

Sellnow, D.D., \& Martin, J.M. (2010). The basic course in communication: Where do we go from here? In D.L. Fassett \& J.T. Warren (Eds.), The Sage handbook of communication and instruction (pp. 3353). Thousand Oaks, CA: Sage Publications, Inc.

Sidelinger, R. J., \& Booth-Butterfield, M. (2010). Co-constructing student involvement: An examination of teacher confirmation and student-to-student connectedness in the college classroom. Communication Education, 59(2), 165-184.

Sprague, J. (1992). Expanding the research agenda for instructional communication: Raising some unasked questions. Communication Education, 41(1), 1-25.

Sprague, J. (1993). Why teaching works: The transformative power of pedagogical communication. Communication Education, 42, 349-366.

Stake, R. (1995). The art of case research. Newbury Park, CA: Sage Publications.

Valett, R. (1977). Humanistic education: Developing the whole person. St Louis, MO: Mosby.

Warren, J. T. (2011). Reflexive teaching: Toward critical autoethnographic practices of/in/on pedagogy. Cultural Studies $\leftrightarrow$ Critical Methodologies, 11(2), 139-144. 


\section{About the Author}

Justin D. Walton (justinw@cameron.edu) is a Professor of Communication Studies at Cameron University. He frequently teaches coursework in public speaking, small group communication, gender communication, research methods, and language and social interaction. His scholarly interests include communication pedagogy, symbolic interactionism, and political discourse. In addition to his teaching and research, Walton serves as the department's Basic Course Director and mentors students concentrating in communication education. 